\title{
Phytochemical Screening, Antimicrobial Properties and Proximate Analysis of Landolphia owariensis P. Beauv Seeds
}

\author{
D. C. Nwokonkwo ${ }^{1}$ \\ ${ }^{1}$ Faculty of Physical Sciences, Department of Industrial Chemistry, Ebonyi State University Abakaliki, Nigeria \\ Correspondence: D. C. Nwokonkwo, Faculty of Physical Sciences, Department of Industrial Chemistry, Ebonyi \\ State University Abakaliki, Nigeria. E-mail: mirinkwa@gmail.com
}

Received: June 16, 2014 Accepted: July 14, 2014 Online Published: July 22, 2014

doi:10.5539/ijc.v6n3p48 URL: http://dx.doi.org/10.5539/ijc.v6n3p48

\begin{abstract}
Phytochemical screening, antimicrobial properties and proximate analysis of the seeds of Landolphia owariensis P. Beauv were investigated. Dried seeds of Landolphia owariensis P. Beauv were pulverized and extracted with 96.5\% ethanol using soxhlet extraction method. The phytochemical screening of the extract revealed the presence of glycosides, saponins and phenols while tannins, flavonoids, alkaloids and steroids were not detected. The crude ethanol extract showed antimicrobial potency against Candida albicans, Streptococcus faecali, Escherichia coli, Pseudomonas aeruginosa, Staphylococcus aureus and Coliform bacilli at the concentrations of $100 \mathrm{mg} / \mathrm{mL} .50 \mathrm{mg} / \mathrm{mL}, 25 \mathrm{mg} / \mathrm{mL}$ and $16.5 \mathrm{mg} / \mathrm{mL}$ with inhibition zone diameter (IZD) values ranging between $16 \mathrm{~mm}-30 \mathrm{~mm}$. The crude sample was partitioned into acidic, basic and neutral metabolites which showed varying degrees of antimicrobial potency at the concentrations of $100 \mathrm{mg} / \mathrm{mL}, 50 \mathrm{mg} / \mathrm{mL}, 25 \mathrm{mg} / \mathrm{mL}$ and 16.5 $\mathrm{mg} / \mathrm{mL}$ against the same organisms. The acidic metabolite showed pronounced antimicrobial activity against these organisms compared to the basic and neutral metabolites. Amoxycillin (amoxyl) and orazone were used as standard antibiotics and levofloxacin as a standard fungicide. The proximate analysis of the untreated seed sample gave $2.27 \%$ ash content, $15.32 \%$ moisture content, $15.70 \%$ crude fiber, $28.06 \%$ crude protein and $48.45 \%$ carbohydrate.
\end{abstract}

Keywords: ethanol extract, metabolite, antimicrobial, proximate analysis, Landolphia owariensis

\section{Introduction}

Naturally occurring useful substances could be sourced from plants, animals or from minerals (Sofowora, 1993). These could be obtained from both primary and metabolic processes and have provided and still provide sources of medicine and pharmaceuticals for ages (Gills, 1992). Medicinal plants and the use of herbs are now sources of many important drugs and food supplements of the modern world and have been documented by some researchers (Harborne, 1973; W. H. Lewis \& M. P. E. Lewis, 1977; Holetz, Pessini, Sanches, Cortez, Nakamura, $\&$ Filho, 2002). They are the bioactive constituents in form the of steroids, terpenoids, carotenoids, flavonoids, alkaloids, tannins, glycosides, saponins, phenols and so on (Addae-Mensah, 1992).

Antimicrobial substances like saponins, glycosides, flavonoids, alkaloids are found well distributed in plants and they are the active principles used as antioxidants, antifungals, antibiotics, anti-inflammatory, heamolytic, antipyretic, analgesics, diuretics, mollusicidals (Ojinnaka \& Nwokonkwo, 2012; Nwokonkwo, 2009; Akinyele, Adu, \& Ayeni, 1996). In herbal and traditional medicine, the part of the plant that contains the active ingredient; leaves, stem, root, seeds and so on is taken in form of an extract, infusion or decoction (Dhir, Craig, \& Berman, 2002; Burkhill, 1985; Daziel, 1993; Ake-Assi \& Guinko, 1991).

Landolphia owariensis P. Beauv belongs to the family apocynaceae commonly called vine rubber and known in the Ibo language of South Eastern Nigeria as Utu. Different parts of this plant are used for the treatment of several ailments. The decoction of the leaves is used as a cure for malaria. The root is soaked in local gin and the extract given in the treatment of gonorrhea (Obute, 2005). The aqueous, methanol and chloroform leaf extracts have shown anti-inflammatory, analgesic and antisecretory properties (Owoyele, Olaleye, Oke, \& Elegbe, 2001). The stem bark had been reported as a vermifuge (Odugbemi \& Akinsulere, 2006) while the latex was used as an enema for intestinal worms and as a natural preservative (Obitte, Chukwu, \& Onyishi, 2010). The ethanol extract of the leaf and root showed antimicrobial activities (Nwaogu, Alisi, Igwe, \& Ujowundu, 2008). Okonkwo (2013) reported the isolation, characterization of bioactive compounds of Landolphia owariensis P. Beauv. 
There is a great need for new antimicrobials as a result of high incidence of multidrug resistant microorganisms. For an example, Staphylococcus aureus was discovered to be resistant to ciprofloxacin, erythromycin and clindamycin while Escherichia coli, Pseudomonas aeruginosa and Klessiella species were implicated in drug resistant bacteria septicaemia in Nigeria (Adegoke, Iberi, Akinpelu, Aiyegoro, \& Mboto, 2010)

In this article, the proximate analysis of the seed of Landolphia owariensis P. Beauv, the phytochemical screening and the antimicrobial and antifungal activities of the ethanol crude extract of the seed as well as the antimicrobial and antifungal activities of the acidic, basic and neutral metabolites of the ethanol crude extract of the seed were considered.

\section{Materials and Methods}

\subsection{Plant Material and Preparation}

The fruits of Landolphia owariensis P. Beauv were collected in February of 2012 from Enugu, Enugu State in Nigeria and authenticated at the Department of Plant Sciences and Technology, Federal University of Technology Owerri Imo State, Nigeria. The seeds were removed from the pulp, washed with distilled water, sun dried for seven days and pulverized. The ground sample was stored in a sterile cellophane bag until needed.

\subsection{Extraction}

Approximately $650 \mathrm{~g}$ of the ground sample was weighed on analytical weighing balance Kern Germany Model 770 and extracted by soxhlet in $1000 \mathrm{~mL}$ ethanol (BDH chemical Ltd. England) for $24 \mathrm{~h}$. The solvent was distilled off to yield $150 \mathrm{~g}$ of brown gummy like substance.

\section{Phytochemical Screening}

Preliminary phytochemical tests were carried out on the crude ethanol extract (Obi \& Onuoha, 2000; Ejele \& Alinor, 2010; Ejele \& Nwokonkwo, 2013).

\subsection{Test for Tannins}

About $2 \mathrm{~mL}$ of the filtrate which was prepared by dissolving $2 \mathrm{~g}$ of the crude sample in $20 \mathrm{~mL}$ of ethanol was added to $5 \mathrm{~mL}$ distilled water and 2 drops of $\mathrm{FeCl}_{3}$ (dissolved in dilute $\mathrm{HCl}$ ). There was no formation of coloured precipitate.

\subsection{Test for Flavonoids}

Approximately $1 \mathrm{~mL}$ of the stock solution was dissolved in $5 \mathrm{~mL} 0.1 \mathrm{M}$ solution of $\mathrm{NaOH}$. To this was added $0.5 \mathrm{M}$ solution of $\mathrm{H}_{2} \mathrm{SO}_{4}$ until the solution became acidic (tested with litmus paper), there was no colour change.

\subsection{Test for Alkaloids}

Wagner's reagent was prepared and $2 \mathrm{~mL}$ of it was added to $2 \mathrm{~mL}$ of the plant sample and shaken vigorously, there was no presence of coloured precipitate.

\subsection{Test for Saponins}

To $2 \mathrm{~mL}$ of the plant sample was added $2 \mathrm{~mL}$ of distilled water and shaken, the agitation produced frothing of the solution. Also to a fresh $2 \mathrm{~mL}$ sample was added $2 \mathrm{~mL}$ of olive oil and shaken vigorously this also produced frothing.

\subsection{Test for Steroids}

Chloroform $2 \mathrm{~mL}$ was added to $2 \mathrm{~mL}$ of the plant sample solution. To this mixture was added carefully $2 \mathrm{~mL}$ conc. $\mathrm{H}_{2} \mathrm{SO}_{4}$. This reaction produced two layers; the upper organic layer and the aqueous lower layer. The organic layer was removed, evaporated to dryness and $5 \mathrm{~mL}$ conc. $\mathrm{H}_{2} \mathrm{SO}_{4}$ added to it. The whole reaction mixture was heated for $10 \mathrm{~min}$ in a water bath, allowed to cool; there was no visible colour change.

\subsection{Test for Glycosides}

To $2 \mathrm{~mL}$ solution of the sample was added $2 \mathrm{~mL}$ chloroform and $2 \mathrm{~mL}$ ice-cold acetic anhydride in $2 \mathrm{~mL}$ conc. $\mathrm{H}_{2} \mathrm{SO}_{4}$. A pink colour which developed slowly into purple colour was observed.

\subsection{Test for Phenols}

Approximately $0.5 \mathrm{~mL}$ of the sample solution was mixed with $4 \mathrm{~mL}$ of distilled water and heated, allowed to cool and filtered. $0.5 \mathrm{~mL} \mathrm{FeCl}_{3}$ was added to the filtrate and a dark-brown precipitate was observed. 


\section{Preparation of Metabolites}

\subsection{Basic Metabolite}

$3.0 \mathrm{~g}$ of the sample was treated with $20 \mathrm{~mL}$ of $0.01 \mathrm{M} \mathrm{HCl}$ and extracted with $30 \mathrm{~mL}$ of chloroform in a separatory funnel and allowed to stay for $3 \mathrm{~h}$ (Ejele \& Akujiobi, 2011). The lower chloroform layer was removed and reserved for the preparation of neutral metabolite. The acid layer was treated with $10 \mathrm{~mL}$ of $0.01 \mathrm{M}$ solution of $\mathrm{NaOH}$ until the mixture became basic. The resulting solution with or without precipitate was allowed to evaporate completely to reveal a gel like substance which was dissolved in $95 \%$ ethanol and filtered. This filtrate was used, without further purification for antibacterial analysis.

\subsection{Neutral Metabolite}

The chloroform layer obtained above was treated with $30 \mathrm{~mL}$ of $0.01 \mathrm{M}$ solution of $\mathrm{NaOH}$. The mixture was allowed to equilibrate for $3 \mathrm{~h}$. The chloroform layer was removed and allowed to dry to give a gel like compound which was dissolved in $95 \%$ ethanol and filtered. The filtrate was used for antimicrobial susceptibility test.

\subsection{Acidic Metabolite}

The aqueous alkaline layer obtained from above was treated with $50 \%$ conc. $\mathrm{HCl}$, the substance obtained was used for antibacterial screening.

\section{Antibacterial Properties of the Extract and the Metabolites}

This analysis was done in Microbiology Department, Federal Medical Center Owerri, Imo State, Nigeria. Test organisms used were Candida albicans, Streptococcus faecali, Escherichia coli, Pseudomonas aeruginosa, Staphylococcus aureus and Coliform bacilli. Microorganisms culture were maintained in Nutrient medium (Merck) for bacteria, and Sabouraud dextrose (Merck) for fungus. The agar-diffusion method was used (George \& Roger, 2002), the microorganisms were maintained on agar slants, and sub-cultures were freshly prepared before use. The bacteria for inoculation were made in $5 \mathrm{~mL}$ of nutrient agar and grown for $24 \mathrm{~h}$ at $37{ }^{\circ} \mathrm{C}$ while the fungus was inoculated $5 \mathrm{~mL}$ Sabouraud broth and grown for $48 \mathrm{~h}$ at $25^{\circ} \mathrm{C}$. The final inoculating agents were made with Nutrient agar medium or Sabouraud agar seeded with the test microorganisms. Plates were prepared by pouring $20 \mathrm{~mL}$ of freshly prepared Nutrient agar or $20 \mathrm{~mL}$ of Sabouraud agar into $20 \mathrm{~mm} \times 100 \mathrm{~mm}$ petri dishes and adjusted to $45^{\circ} \mathrm{C}$. The inoculums $(5 \mathrm{~mL})$ were poured directly over the surface of the prepared plates, allowed to solidify for $5 \mathrm{~min}$; a cork borer of $1 \mathrm{~cm}$ was used to penetrate the medium. $1 \mathrm{~mL}$ of the ethanol plant extract was inoculated into each borer, and the plates incubated at $35^{\circ} \mathrm{C}$ for both the bacteria and fungus. After $24 \mathrm{~h}$ incubation, inhibition zones were recorded as the diameter of the growth free zones. Amoxycillin and Orazone at $30 \mathrm{mg} / \mathrm{mL}$ respectively were used as positive controls for bacteria and $30 \mathrm{mg} / \mathrm{mL}$ Levofloxacin for the fungus.

\section{Proximate Analysis}

The proximate analysis was carried out using the methods of Association of Official Analytical Chemist, AOAC (2005). The parameters considered for proximate analysis included sample ash content, moisture content, crude fiber, crude protein and carbohydrate.

\section{Results}

The result of the phytochemical screening of the crude ethanol extract is shown on Table 1. Antibacterial properties of the crude extract, the basic, neutral and acidic metabolites against the microorganisms at different concentrations are shown on Tables 2- 6 while the proximate analysis result is shown on Table 7.

Table 1. Phytochemical screening of the crude extract

\begin{tabular}{llc}
\cline { 2 - 2 } Phytochemicals & Result \\
\cline { 2 - 2 } Tannins & - \\
Flavonoids & - \\
Alkaloid & - \\
Steroids & - \\
Saponins & + \\
Glycosides & + \\
Phenols & + \\
\hline
\end{tabular}

- (Absent), + (Present). 
Table 2. Antibacterial properties of the crude extract

\begin{tabular}{llllll}
\hline Test Organisms & \multicolumn{5}{l}{ Diameter of Zone of Inhibition(mm) } \\
\hline & \multicolumn{4}{l}{ Concentration (mg/mL) } \\
& 100 & 50 & 25 & 12.5 & 6.25 \\
\hline Candida albicans & 25 & 19 & 15 & 9 & - \\
Escherichia coli & 30 & 23 & 16 & 10 & - \\
Pseudomonas aeruginosa & 20 & 14 & 10 & - & - \\
Streptococcus faecalis & 15 & 10 & - & - & - \\
Staphylococcus aureus & 20 & 14 & - & - & - \\
Coliform bacilli & - & - & - & - & - \\
\hline
\end{tabular}

- (no activity), 9 -19 (ineffective), 20- 23 (effective), 25- 30 (strongly effective).

Table 3. Antibacterial properties of the basic metabolite

\begin{tabular}{llllll}
\hline Test Organisms & \multicolumn{7}{l}{ Diameter of Zone of Inhibition(mm) } \\
\hline & \multicolumn{4}{l}{ Concentration (mg/mL) } \\
& 100 & 50 & 25 & 12.5 & 6.25 \\
\hline Candida albicans & 30 & 20 & 15 & 10 & - \\
Escherichia coli & 30 & 25 & 20 & 10 & - \\
Pseudomonas aeruginosa & 30 & 24 & 16 & 12 & - \\
Streptococcus faecalis & 20 & 14 & 10 & - & - \\
Staphylococcus aureus & - & - & - & - & - \\
Coliform bacilli & - & - & - & - & - \\
\hline
\end{tabular}

- (no activity), 10 -16 (ineffective), 20- 24 (effective), 25- 30 (strongly effective).

Table 4. Antibacterial properties of the neutral metabolite

\begin{tabular}{llllrl}
\hline Test Organisms & \multicolumn{5}{l}{ Diameter of Zone of Inhibition(mm) } \\
\hline & Concentration (mg/mL) & & \\
& 100 & 50 & 25 & 12.5 & 6.25 \\
\hline Candida albicans & - & - & - & - & - \\
Escherichia coli & - & - & - & - & - \\
Pseudomonas aeruginosa & 30 & 23 & 17 & 10 & - \\
Streptococcus faecalis & 22 & 15 & 10 & - & - \\
Staphylococcus aureus & 25 & 19 & 12 & 6 & - \\
Coliform bacilli & 30 & 24 & 16 & 10 & - \\
\hline
\end{tabular}

- (no activity), 6- 19 (ineffective), 22- 24 (effective), 25- 30 (strongly effective). 
Table 5. Antibacterial properties of the acidic metabolite

\begin{tabular}{|c|c|c|c|c|c|}
\hline \multirow[t]{3}{*}{ Test Organisms } & \multicolumn{5}{|c|}{ Diameter of Zone of Inhibition(mm) } \\
\hline & \multicolumn{5}{|c|}{ Concentration (mg/mL) } \\
\hline & 100 & 50 & 25 & 12.5 & 6.25 \\
\hline Candida albicans & 30 & 24 & 16 & 10 & - \\
\hline Escherichia coli & 25 & 18 & 13 & 6 & - \\
\hline Pseudomonas aeruginosa & 34 & 27 & 20 & 13 & - \\
\hline Streptococcus faecalis & 30 & 25 & 19 & 12 & - \\
\hline Staphylococcus aureus & 35 & 28 & 20 & 14 & - \\
\hline Coliform bacilli & 30 & 23 & 15 & - & - \\
\hline
\end{tabular}

- (no activity), 6-18 (ineffective), 20- 23 (effective), 25- 35 (strongly effective).

Table 6. Antibacterial properties of the control drugs

\begin{tabular}{lccc}
\hline Test Organisms & \multicolumn{3}{l}{ Diameter of Zone of Inhibition(mm) } \\
\hline & Concentration $(30 \mathrm{mg} / \mathrm{mL})$ & \\
& Amoxyl & Orazone & Levofloxacin \\
\hline Candida albicans & - & - & - \\
Escherichia coli & 30 & 5 & 30 \\
Pseudomonas aeruginosa & 22 & - & 17 \\
Streptococcus faecalis & - & - & - \\
Staphylococcus aureus & 10 & 15 & 20 \\
Coliform bacilli & - & 10 & 7 \\
\hline
\end{tabular}

- (No activity), 5-17 (ineffective), 20- 22 (effective), 30 (strongly effective).

Table 7. Proximate analysis of the seeds of Landolphia owariensis

\begin{tabular}{lc}
\hline Parameters & Result (\%) \\
\hline Ash & $2.27 \pm 2$ \\
Moisture & $15.32 \pm 4$ \\
Crude Protein & $28.06 \pm 3$ \\
Fiber & $15.70 \pm 2$ \\
Carbohydrate & $48.45 \pm 2$ \\
\hline
\end{tabular}

\section{Discussion}

Preliminary phytochemical screening result revealed the presence of saponins, glycosides and phenols in the ethanol seed extract of Landolphia owariensis P. Beauv, tannin, alkaloids and steroids were absent, Table1.

The crude ethanol extract showed antimicrobial potency against Candida albicans and Escherichia coli, moderate activity against Pseudomonas aeruginosa, and Staphylococcus aureus in the concentrations of 100 $\mathrm{mg} / \mathrm{mL}$. At $50 \mathrm{mg} / \mathrm{mL}$, the extract was effective against Escherichia coli. There was inhibition against coliform bacilli and no inhibition at $25 \mathrm{mg} / \mathrm{mL}$ and $12.5 \mathrm{mg} / \mathrm{mL}$ concentrations and no activity at all at $6.25 \mathrm{mg} / \mathrm{mL}$, Table 2.

In Table 3, the basic metabolite inhibited the growth of Candida albicans, Escherichia coli and Pseudomonas aeruginosa at $100 \mathrm{mg} / \mathrm{mL}$ concentration with inhibition zone diameters of $30 \mathrm{~mm}$ respectively and bacteriastatic against Streptococcus faecalis at the same concentration. At $50 \mathrm{mg} / \mathrm{mL}$ the extract was bacteriastatic against the same pathogens even at $25 \mathrm{mg} / \mathrm{mL}$ where the extract showed some activity against Escherichia coli. The basic metabolite did not show any inhibitory activity against Staphylococcus aureus and Coliform bacilli. 
The neutral metabolite showed strong antimicrobial sensitivity at $100 \mathrm{mg} / \mathrm{mL}$ for Pseudomonas aeruginosa and Coliform bacilli mildly active against Streptococcus faecalis and Staphylococcus aureus. There was considerable activity against Pseudomonas aeruginosa and Coliform bacilli at $50 \mathrm{mg} / \mathrm{mL}$ concentration, Table 4.

The acidic metabolite showed strong inhibition against five of the six pathogens at $100 \mathrm{mg} / \mathrm{mL}$ with IZD of 30 $\mathrm{mm}$ and above, it showed mild inhibitory activity against Escherichia coli with IZD value of $25 \mathrm{~mm}$. Even at 50 $\mathrm{mg} / \mathrm{mL}$ and at more dilute concentration of $25 \mathrm{mg} / \mathrm{mL}$; the extract still exhibited antimicrobial sensitivity.

At more dilute concentrations of $12.5 \mathrm{mg} / \mathrm{mL}$ and $6.25 \mathrm{mg} / \mathrm{mL}$ of all the metabolites, no significant sensitivity was observed. Comparatively, the acidic metabolite was effective against all the pathogens, suggesting that this metabolite could be used as a source of effective and potent antimicrobial/antifungal drugs. Comparison of the inhibitory activity of the extract with the control antibiotic drugs (amoxyl, orazone and levofloxacin) in table 6 revealed that the metabolites of the ethanolic extract of Landolphia owariensis P. Beauv seed showed significantly higher inhibitory activity than these drugs.

The antimicrobial potency of this extract was attributed to the presence of saponins, glycosides and phenols and supports the use of this species of plant in traditional or herbal medicine. The partitioning of the seed extract into the different metabolites had provided an easy method for carrying out a bio-assay guided isolation, purification and characterization of the acidic metabolite.

The results obtained from the proximate analysis of the crude plant extract in Table 7; gave ash content $2.27 \pm 2 \%$, moisture content $15.32 \pm 4 \%$, crude fiber $15.70 \pm 3 \%$, crude protein $28.06 \pm 3 \%$ and carbohydrate $48.45 \pm 2 \%$ respectively. The crude fiber, crude protein and carbohydrate composition of the seed extract are important because of their nutritive values; this showed that the plant seeds could be a good source of nutrition for body building.

\section{References}

Addae-Mensah, I. (1992). Towards a rational scientific basis for herbal medicine-A Phytochemist's two Decades Contribution. An Inaugural lecture delivered at the University of Ghana. Ghana University Press Accra.

Adegoke, A. A., Iberi, P. A., Akinpelu, D. A., Aiyegoro, O. A., \& Mboto, A. (2010). Studies on the phytochemical screening and antimicrobial potentials of phllanthus amarus against multiple antibiotic resistant bacteria. International Journal of Applied Research in Natural Products, 3(3), 6-12.

Ake-Assi, L., \& Guinko, S. (1991), Plants used in Traditional Medicine in West Africa. Swiss Center for Scientific Research, Ivory Coast and Roche African Research Foundation, 78.

Akinyele, O. B., Adu, O. E., \& Ayeni, I. A. (1996). Studies of some biological and chemical characteristics of Mexican sunflower (Tithonia diversifolia). Consultation Research Journal, 1(1), 35-38.

AOAC. (2005). Official Methods of Analysis (15th ed.). Association of Official Analytical Chemist: Washington D. C.

Burkhill, H. M. (1985). A Review of Dalziel's: The useful Plants of West Africa. Royal Botanical Garden: Kew.

Dalziel, J. M. (1993). Useful Plants of West Tropical Africa. Crown Agents for the Colonies: London.

Dhir, M. L., Crayg, G., \& Berman, F. W. (2002). Screening of indian plants for biological activity. India Journal of Experimental Biology, 6, 237-247.

Ejele, A. E., \& Akujiobi, G. O. (2011). Effects of secondary metabolite of garcinia kola on the microbial spoilage of cajanus cajan extract. International Journal of Tropical Agriculture and Food Systems, 5(1), 8-14.

Ejele, A. E., \& Alinor, J. I. (2010). Anti-sickling potentials of aloe vera extract. Effects of acidic, basic and neutral metabolites on the gelling and sickling of human hbss erythrocytes. International Journal of Natural and Applied Science, 6(2), 155-160.

Ejele, A. E., \& Nwokonkwo, D. C. (2013). Effect of microbial Spoilage on antimicrobial potential and phytochemical composition of ipecae root extract. International Research Journal of Microbiobiology, 4(4), 106-112.

George, D. P., \& Roger, M. D. (2002). Encyclopaedia of Medicinal Plant (5th ed.). Spainish 1.

Gills, L. S. (1992). Ethnomedical Uses of Plants in Nigeria. Benin: Nigeria: University of Benin Press.

Harborne, J. B. (1973). Phytochemical Methods. Chapman and Hall Ltd: London.

Holetz, F., Pessini, G., Sanches, N., Cortez, D., Nakamura, C., \& Filho, D. (2002). Screening of Some Plants used in the Brazillian Folk Medicine for the Treatment of Infectious Diseases. Mem Inst Oswald Cruz Rio 
de Janeiro, 97(7), 1027-1031. http://dx.doi.org/10.1590/S0074-02762002000700017

Lewis, W. H., \& Lewis, M. P. E. (1977). Medicinal Botany. New York: John Wiley and Sons.

Nwaogu, L. A., Alisi, C. S., Igwe, C. U., \& Ujowundu, C. O. (2008). A comparative study of the antimicrobiall properties of the ethanolic extracts of Landolphia owariensis leaf and root. African Journal of Biotechnology, 7, 368-372.

Nwokonkwo, D. C. (2009). Phytochemical constitution and antimicrobial activity of the stem bark of ficus asperifolia (Sand paper) tree. Journal of Chemical Society of Nigeria, 34(2), 119-122.

Obi, V. I., \& Onuoha, C. (2000). Extraction and Characterization Methods of Plants and Plant Products. Webs media Publishers: Owerri.

Obitte, N. C., Chukwu, A., \& Onyishi, V. (2010). The physicochemical evaluation of and applicability of Landolphia owariensis latex as release modulating agent in its admixture with carbosil in ibuprofen loaded self emulsifying oil formulations. International Journal of Applied Research in Natural Products, 2, 27-43.

Obute, G. C. (2005). Ethno-medicinal Plant Resources of Eastern Ngeria. Retrieved March 23, 2012, from http://www.siu.edu

Odugbemi, T., \& Akinsulere, O. (2006). Medicinal Plants by Species names. Outlines and Pictures of Medicinal Plants from Nigeria. Nigeria: University of Lagos Press.

Ojinnaka, C, M., \& Nwokonkwo, D. C. (Nee Okpala) (2012). A molluscicidal triterpenoid saponin from the fruits of napoleonaea p. beauv (lecythidaceae). Journal of Applied Science and Environmental Management, $16(2), 213-216$.

Okonkwo, J. N. (2013). Isolation and characterization of potential bioactive compounds of Landolphia owariensis. International Journal of Applied Research in Natural Products, 6(3), 23.

Owoyele, B. V. et al. (2001). Anti-inflammatory and analgesic activities of the leaf extract of landolphia Owariensis. African Journal of Biomedical Research, 1, 131-133.

Sofowora, E. A. (1993). Medicinal Plants and Traditional Medicine in Africa. Ibadan, Nigeria: Spectrum Books Ltd.

\section{Copyrights}

Copyright for this article is retained by the author(s), with first publication rights granted to the journal.

This is an open-access article distributed under the terms and conditions of the Creative Commons Attribution license (http://creativecommons.org/licenses/by/3.0/). 